\title{
How Human Alpha-lactalbumin Recognize DNA and RNA
}

\section{Nevinsky GA ${ }^{1 *}$, Alinovskaya $\mathrm{LI}^{1}$, Ivanisenko $\mathrm{NV}^{2}$, Soboleva $\mathrm{SE}^{1}$ and Sedykh $\mathrm{SE}^{1}$}

${ }^{1}$ Institute of Chemical Biology and Fundamental Medicine, 8 Lavrentiev Ave, Novosibirsk 630090, Russia

${ }^{2}$ Institute of Cytology and Genetics, Siberian Division of Russian Academy of Sciences, 10 Lavrentiev Ave., 630090 Novosibirsk, Russia

\begin{abstract}
Human a-lactalbumin (LA) has an important function in mammary cells, activates the caspases involving in apoptosis. LA complex interacts with DNA in tumor cells with histones and impaired the chromatin structure. There are no any data on how LA recognizes DNA and interact with histones and DNA of chromatin. The approach of stepwise increase in ligand complexity was used for estimation of the relative contribution of every DNA nucleotide unit to its total affinity for human LA. It was shown that the LA DNA-binding site minimal ligands are orthophosphate and all dNMPs and rNMPs $\left(K_{\mathrm{d}}=(5.0-43) \times 10^{-5}\right)$. Maximal contribution to the total affinity was observed for three nucleotide units of all $(\mathrm{pN})_{n}$ with a significant decrease in the order $1>2>3$, at $n=4-6$ it was remarkably lower and at $n \geq 6-7$ all dependencies of $-\log K_{d}$ upon $n$ reached plateaus. Double-stranded $(\mathrm{pN})_{n}$ showed significantly lower affinity comparing with singlestranded ligands. The thermodynamic parameters characterizing the specific contribution of $(\mathrm{pN})_{1-6}$ every nucleotide link $\left(\Delta G^{\circ}\right)$ to their total affinity for LA were estimated. The spatial model of LA-DNA complex was calculated. LA protein sequence has homology with those of five histones $(\mathrm{H} 1-\mathrm{H} 4)$ involved in the chromatin nucleus interactions between themselves and their complex with DNA. It is assumed that the homology may be the main reason for the interaction of LA with chromatin DNA, leading to a breakdown in its structure, as well as the proper binding of histones between themselves and with DNA.
\end{abstract}

Keywords: Human a-lactalbumin; Recognition of DNA and RNA; General regularities of DNA recognition; Thermodynamic model of recognition

Abbreviations: AA: Amino Acid; LA: Alpha-Lactalbumin; ODNs: Deoxyoligonucleotides; ORNs: Ribooligonucleotides; SDS-PAGE: SDSPolyacrylamide Gel Electrophoresis; SILC: Stepwise Increase in Ligand Complexity; ss and ds: Single- and Double-Stranded Oligonucleotides

\section{Introduction}

Components of human milk (proteins, fatty acids, carbohydrates, minerals, and vitamins) provide the necessary set of dietary factors for infant growth, affect the immune system, cognitive development, and positively modulate the intestinal microflora [1]. The unique composition of milk and its biological properties makes the milk attractive for different kinds of research. Human milk contains a lot of various proteins with different biological functions. The concentration of proteins in human milk is high in the early lactation (3\% by weight), and then it gradually decreases to a relatively low level $(0.8-1.0 \%$ in mature milk) [2].

Human milk a-lactalbumin (LA) is one of the major proteins, and its content is $10-20 \%$ of the total protein $(1-1.5 \mathrm{mg} / \mathrm{ml})$ [3]. This protein with molecular mass $14.1 \mathrm{kDa}$ is a homolog of lysozyme. LA consists one polypeptide chain containing 123 amino acid (AA) residues. Natural LA consists of two domains: a large $\alpha$-helical domain and a small $\beta$-fold domain. Domains held together with a cysteine bridge, forming the $\mathrm{Ca}^{2+}$-binding loop [3]; it binds to calcium in molar 1:1 ratio [4]. The calcium-binding $a$-lactalbumin has drastically changed the Stokes radius of the LA, and the protein becomes much more compact. LA performs an important function in the secrets of mammary cells: this is one of two components lactosaminated catalyzing the last stage of the biosynthesis of lactose. It was shown that $\alpha$-lactalbumin aromatic cluster of a substructure adjacent to the cleft, it is important for LA interaction with galactosyltransferase and effects on binding of glucose in the lactose synthase complex [5].

The activation of different caspases playing a central role in the signaling and execution steps of apoptosis by a folding variant of specific human alpha-lactalbumin (MAL) isolated from human milk was studied. It was shown that MAL activates the caspases involving in apoptosis and that direct MAL interaction with mitochondria results in the release of cytochrome c, suggesting that this release may be an important step in the initiation as well as amplification of the caspase cascade in Jurkat and A549 cells [6].

It was proposed that $\alpha$-lactalbumin is an example of a protein that can acquire different functions depending on its folding state [7]. First, it was shown that native $\alpha$-LA from human milk cannot induce apoptosis, while its complex from acid-precipitated milk casein was shown able to induce apoptosis in tumor and immature cells, but not in mature, differentiated cells [8]. HAMLET ( $\alpha$-LA of humans made lethal to tumor cells) is shown to consist of partially unfolded $\alpha$-lactalbumin that bound with a cofactor stabilizing protein specific conformation. This cofactor was identified as a specific fatty oleic acid [9]. It has been found that $\alpha$-LA may be not the main cytotoxic component of its complexes with oleic acid, but the acid is more important $[10,11]$.

HAMLET was shown to bind strongly with $\mathrm{H} 3$ and to a lesser extent with $\mathrm{H} 4$ and $\mathrm{H} 2 \mathrm{~b}$ histones [12]. In vivo, in tumor cells HAMLET co-localized with histones and impaired the chromatin structure. In vitro, HAMLET bound strongly with histones and disturbed their

*Corresponding author: Nevinsky GA, Institute of Chemical Biology and Fundamental Medicine, 8 Lavrentiev Ave, Novosibirsk 630090, Russia, Tel: +7383-3635126; E-mail: nevinsky@niboch.nsc.ru

Received: October 29, 2018; Accepted: November 02, 2018; Published November 09, 2018

Citation: Nevinsky GA, Alinovskaya LI, Ivanisenko NV, Soboleva SE, Sedykh SE (2018) How Human Alpha-lactalbumin Recognize DNA and RNA. (Avocardo) Seed Oil Using Gas Chromatography-Mass Spectroscopy. Biochem Anal Biochem 7: 363. doi: $10.4172 / 2161-1009.1000363$

Copyright: (c) 2018 Nevinsky GA, et al. This is an open-access article distributed under the terms of the Creative Commons Attribution License, which permits unrestricted use, distribution, and reproduction in any medium, provided the original author and source are credited. 
deposition on DNA. It was concluded that HAMLET interacting with histones and chromatin in nuclei of tumor cells and proposed that such interaction leads to cells death due to irreversible disrupting chromatin organization.

It was presumed that most biological processes are carried out by complexes of different proteins and enzymes [13,14]. Many human milk components are multifunctional and cooperating with many other factors can produce specific effects modulating growth and development of neonates [15]. Recently, a very stable high molecular mass ( 1000 $\mathrm{kDa})$ multiprotein complex from fifteen preparations of human milk was purified and characterized [16]. All very stable complexes from different milk were similar and contained $\alpha$-lactalbumin and lactoferrin as major proteins, while $\beta$-casein, human milk albumin, and immunoglobulins were present in moderate or minor amounts.

It was shown that $\alpha$-LA interacts with calf-thymus DNA [17]. All stable milk protein complexes hydrolyzed efficiently DNA [16]. The question of how individual proteins and their complexes with other proteins recognize DNA is a very important question in molecular biology.

The most informative method of protein-DNA complexes analysis is X-ray crystallography (for reviews see [18-25] and references therein). However, X-ray data cannot provide quantitative estimates of the relative contributions of strong and weak specific and nonspecific individual contacts to the total affinity of proteins for DNA [26-29]. For evaluation of the relative contributions of every individual nucleotide unit of long DNA to the total enzyme affinity for DNA, the approach of stepwise increase in ligand complexity (or SILC) was developed [2629]. Many DNA-dependent enzymes interacting with various DNAs of different structures or sequences including enzymes of replication, repair, topoisomerization, integration, restriction, and several other types were analyzed using the SILC approach [30-44]. It was shown that high affinity (depending on enzyme $5-8$ orders of magnitude) is mainly provided by weak additive interactions between the enzymes and DNA mononucleotides, which are within the DNA-binding cleft (depending enzyme $n=7-20$ ). Interaction of enzymes with specific comparing with nonspecific DNA is accompanied by a strengthening of some contacts existing for nonspecific DNA and by the formation of new specific contacts. However, specific contacts of enzymes with cognate DNAs are usually weak, and their relative contribution to the total affinity of DNAs to enzymes does not exceed 1-2 orders of magnitude. In addition, both DNAs and enzymes after binding undergo multiple conformational changes leading to the formation of the catalytically proficient structure and the reaction rate for specific DNAs comparing with nonspecific ones increases by 6-8 orders of magnitude. The specificity of all DNA-dependent enzymes is provided due to the enzyme-dependent adjustment of DNA conformation and directly by chemical step of the catalysis [24-26].

In the literature, there is no any data on the structural determinants of DNA-ligands, including evaluation of the relative contribution of their mononucleotide units to the total affinity of oligonucleotides and DNA to proteins without catalytic activities. It was shown that a-lactalbumin interacts with polymeric DNA [17] and with histones distributing their deposition on DNA [12]. However, these results do not contribute to an understanding of a possible mechanism of DNA and histones recognition by $a$-lactalbumin.

Here we report the first analysis of specific regularities of DNA recognition by a-lactalbumin. The SILC approach was used to probe for interactions of $\alpha$-LA with a series of model single-stranded and double-stranded oligonucleotides, and the results are analyzed using a thermodynamic model of DNA recognition. An analysis was made of how the LA can interact with histones and can influence on the interaction between histones and their complex with DNA.

\section{Materials and Methods}

\section{Chemicals used}

Reagents used in this work were obtained mainly from Sigma and Merck. All deoxy- and ribo-oligonucleotides were prepared from commercially available phosphoramidites (Glen Research, Sterling, VA) on an ASM-700 synthesizer (BIOSSET, Novosibirsk, Russia). The sequences of ODNs and ORNs used in this work are given in Tables 1 and 2. All ODNs and ORNs were homogeneous according to data of reversed-phase chromatography. Complementary oligonucleotides we annealed using standard approach.

Milk of ten donors was used for the purification of LA. The milk sampling protocol conformed to the local hospital human ethics committee guidelines (Ethics committee of Novosibirsk State Medical University, Russia). Institutional ethics committee specifically approved this study including written consent of donors to present their milk for scientific study in accordance with Helsinki ethics committee guidelines.

\section{LA purification}

Electrophoretically homogeneous LA preparations were obtained from ten milk of healthy mothers. The milk samples $(500 \mathrm{ml})$ were centrifuged twice for $40 \mathrm{~min}$ at $12000 \mathrm{rpm}$ (Beckman Coulter Avanti J-E, rotor JA-14). After each centrifugation, lipid layer at the top and the cells and protein precipitates from the bottom were removed. Then milk proteins were precipitated by ammonium sulfate followed by phenyl-Sepharose chromatography and gel filtration on a Sephadex

\begin{tabular}{|c|c|c|c|c|c|}
\hline Ligand & $n$ & $K_{d^{\prime}} \cdot M^{*}$ & Ligand & $n$ & $K_{\mathrm{d}} \cdot \mathbf{M}^{*}$ \\
\hline Orthophosthate & 0 & $1.0 \times 10^{-3}$ & - & - & - \\
\hline$d(p A)$ & 1 & $5.0 \times 10^{-5}$ & $d(p T)$ & 1 & $3.0 \times 10^{-4}$ \\
\hline $\mathrm{d}(\mathrm{pA})_{2}$ & 2 & $5.3 \times 10^{-6}$ & $\mathrm{~d}(\mathrm{pT})_{2}$ & 2 & $6.5 \times 10^{-5}$ \\
\hline $\mathrm{d}(\mathrm{pA})_{3}$ & 3 & $2.8 \times 10^{-6}$ & $\mathrm{~d}(\mathrm{pT})_{3}$ & 3 & $9.4 \times 10^{-6}$ \\
\hline $\mathrm{d}(\mathrm{pA})_{4}$ & 4 & $6.6 \times 10^{-7}$ & $\mathrm{~d}(\mathrm{pT})_{4}$ & 4 & $1.8 \times 10^{-6}$ \\
\hline $\mathrm{d}(\mathrm{pA})_{5}$ & 5 & $2.4 \times 10^{-7}$ & $\mathrm{~d}(\mathrm{pT})_{5}$ & 5 & $1.4 \times 10^{-6}$ \\
\hline$d(p A)_{6}$ & 6 & $8.8 \times 10^{-8}$ & $d(p T)_{6}$ & 6 & $9.0 \times 10^{-7}$ \\
\hline $\mathrm{d}(\mathrm{pA})_{7}$ & 7 & $8.8 \times 10^{-8}$ & $\mathrm{~d}(\mathrm{pT})_{8}$ & 8 & $1.0 \times 10^{-6}$ \\
\hline $\mathrm{d}(\mathrm{pA})_{8}$ & 8 & $1.0 \times 10^{-7}$ & $\mathrm{~d}(\mathrm{pT})_{10}$ & 10 & $2.4 \times 10^{-6}$ \\
\hline$d(p A)_{11}$ & 11 & $1.3 \times 10^{-7}$ & $d(p T)_{11}$ & 11 & $1.1 \times 10^{-5}$ \\
\hline$d(p A)_{13}$ & 13 & $1.6 \times 10^{-7}$ & $d(p T)_{12}$ & 12 & $1.5 \times 10^{-5}$ \\
\hline$d(p A)_{16}$ & 16 & $1.2 \times 10^{-6}$ & $\mathrm{~d}(\mathrm{pT})_{14}$ & 14 & $1.9 \times 10^{-5}$ \\
\hline$d(p A)_{20}$ & 20 & $2.2 \times 10^{-6}$ & $\mathrm{~d}(\mathrm{pT})_{16}$ & 16 & $8.6 \times 10^{-5}$ \\
\hline$d(p A)_{24}$ & 24 & $2.9 \times 10^{-6}$ & $d(p T)_{24}$ & 24 & $1.1 \times 10^{-4}$ \\
\hline $\mathrm{d}(\mathrm{pC})$ & 1 & $1.2 \times 10^{-4}$ & $\mathrm{~d}(\mathrm{pC})_{8}$ & 8 & $5.0 \times 10^{-7}$ \\
\hline $\mathrm{d}(\mathrm{pC})_{2}$ & 2 & $3.0 \times 10^{-5}$ & $\mathrm{~d}(\mathrm{pC})_{9}$ & 9 & $5.3 \times 10^{-7}$ \\
\hline $\mathrm{d}(\mathrm{pC})_{3}$ & 3 & $1.2 \times 10^{-6}$ & $d(p C)_{10}$ & 10 & $2.6 \times 10^{-6}$ \\
\hline $\mathrm{d}(\mathrm{pC})_{4}$ & 4 & $5.5 \times 10^{-7}$ & $d(p C)_{12}$ & 12 & $1.2 \times 10^{-5}$ \\
\hline$d(p C)_{5}$ & 5 & $2.2 \times 10^{-7}$ & $d(p C)_{16}$ & 16 & $1.6 \times 10^{-4}$ \\
\hline $\mathrm{d}(\mathrm{pC})_{6}$ & 6 & $2.1 \times 10^{-7}$ & $\mathrm{~d}(\mathrm{pC})_{24}$ & 24 & $1.8 \times 10^{-4}$ \\
\hline $\mathrm{d}(\mathrm{pA})_{6} \times \mathrm{d}(\mathrm{pT})_{6}$ & 6 & $1.8 \times 10^{-7}$ & $\mathrm{~d}(\mathrm{pA})_{16} \times \mathrm{d}(\mathrm{pT})_{16}$ & 16 & $8.5 \times 10^{-6}$ \\
\hline $\mathrm{d}(\mathrm{pA})_{12} \times \mathrm{d}(\mathrm{pT})_{12}$ & 12 & $1.2 \times 10^{-6}$ & $\mathrm{~d}(\mathrm{pA})_{20} \times \mathrm{d}(\mathrm{pT})_{20}$ & 20 & $1.7 \times 10^{-5}$ \\
\hline
\end{tabular}

The values of $K_{d}$ were estimated from the Scatchard plots; the average of three independent experiments: the determination error did not exceed $10-15 \%$.

Table 1: The affinity of $\alpha$-lactalbumin for orthophosphate, dNMP, single- and double-stranded ODNs. 
Citation: Nevinsky GA, Alinovskaya LI, Ivanisenko NV, Soboleva SE, Sedykh SE (2018) How Human Alpha-lactalbumin Recognize DNA and RNA (Avocardo) Seed Oil Using Gas Chromatography-Mass Spectroscopy. Biochem Anal Biochem 7: 363. doi: 10.4172/2161-1009.1000363

Page 3 of 8

\begin{tabular}{|c|c|c|c|c|c|}
\hline Ligand & $\mathbf{n}$ & $K_{d}, M^{*}$ & Ligand & $\mathrm{n}$ & $K_{d^{\prime}}, \mathbf{M}^{*}$ \\
\hline Orthophosphate & 0 & $1.0 \times 10^{-3}$ & - & - & - \\
\hline$r(p A)$ & 1 & $2.3 \times 10^{-4}$ & $r(p U)$ & 1 & $4.3 \times 10^{-4}$ \\
\hline$r(p A)_{2}$ & 2 & $4.0 \times 10^{-5}$ & $r(p U)_{3}$ & 3 & $3.8 \times 10^{-5}$ \\
\hline$r(p A)_{4}$ & 4 & $2.6 \times 10^{-6}$ & $r(p U)_{4}$ & 4 & $3.0 \times 10^{-5}$ \\
\hline$r(p A)_{5}$ & 5 & $3.3 \times 10^{-7}$ & $r(p U)_{5}$ & 5 & $1.1 \times 10^{-5}$ \\
\hline$r(p A)_{6}$ & 6 & $1.5 \times 10^{-7}$ & $r(p U)_{6}$ & 6 & $2.2 \times 10^{-6}$ \\
\hline$r(p A)_{8}$ & 8 & $1.8 \times 10^{-7}$ & $r(p U)_{8}$ & 8 & $2.2 \times 10^{-6}$ \\
\hline$r(p A)_{10}$ & 10 & $1.0 \times 10^{-6}$ & $r(p U)_{9}$ & 9 & $4.8 \times 10^{-6}$ \\
\hline$r(p A)_{19}$ & 19 & $8.1 \times 10^{-6}$ & $r(p U)_{14}$ & 14 & $1.1 \times 10^{-5}$ \\
\hline$r(p A)_{24}$ & 24 & $8.8 \times 10^{-6}$ & - & - & - \\
\hline$r(p C)$ & 1 & $3.0 \times 10^{-4}$ & $r(p C)_{6}$ & 6 & $2.2 \times 10^{-6}$ \\
\hline $\mathrm{r}(\mathrm{pC})_{3}$ & 2 & $3.5 \times 10^{-5}$ & $\mathrm{r}(\mathrm{pC})_{8}$ & 8 & $2.2 \times 10^{-6}$ \\
\hline $\mathrm{r}(\mathrm{pC})_{4}$ & 4 & $2.0 \times 10^{-5}$ & $\mathrm{r}(\mathrm{pC})_{9}$ & 9 & $3.0 \times 10^{-6}$ \\
\hline$r(p C)_{5}$ & 5 & $6.6 \times 10^{-6}$ & $r(p C)_{12}$ & 12 & $8.8 \times 10^{-6}$ \\
\hline
\end{tabular}

'The values of $K_{\mathrm{d}}$ were estimated from the Scatchard plots; the average of three independent experiments: the determination error did not exceed $10-15 \%$

Table 2: The affinity of a-lactalbumin for orthophosphate, rNMP, and ribooligonucleotides.

G-50 column [45]. To protect LA from bacterial contamination, the preparations were sterilized by filtration through a Millex filter (pore size $0.1 \mu \mathrm{m})$. To analyze an "average" situation concerning homogeneity of LA, a mixture of equal amounts of 10 preparations (LA mix $_{\text {mix }}$ ) was prepared. The homogeneity of LA ${ }_{\text {mix }}$ was confirmed by SDS-PAGE with following silver staining.

\section{Crosslinking of LA molecules}

The analysis of LA molecules interaction leading to the formation of their complexes was carried out using glutaric dialdehyde. The reaction mixture $(20 \mu \mathrm{l})$ contained $25 \mathrm{mM}$ HEPES- $\mathrm{NaOH}(\mathrm{pH} 6.0), 0.3 \mathrm{mg} / \mathrm{ml}$ $\mathrm{LA}$, and $0.5 \mathrm{mM}$ glutaric dialdehyde. The mixtures were incubated for 1 hours at $22^{\circ} \mathrm{C}$. Separation of LA cross-linked forms were performed using SDS-PAGE in $4-18 \%$ gradient gels $(0.1 \%$ SDS), and polypeptides were visualized by silver staining.

\section{Fluorescence measurements}

Fluorescence was measured using Cary Eclipse (Varian) spectrofluorimeter at $22^{\circ} \mathrm{C}$. Excitation was performed at $287 \mathrm{~nm}$ while fluorescence emission detected at $344 \mathrm{~nm}$. The reaction mixture contained $20 \mathrm{mM}$ Tris- $\mathrm{HCl}(\mathrm{pH} 7.5)$ and $0.3 \mathrm{mg} / \mathrm{ml} \mathrm{LA}$. Aliquots (1.0-5.0 $\mu \mathrm{l})$ of different oligonucleotides were consecutively added to the mixture, and changes in the LA fluorescence $(\Delta F)$ were recorded, with correction for dilution. The $K_{\mathrm{d}}$ values of LAON complexes were calculated from the Scatchard equation $\Delta F=\Delta F_{\max }-K_{d}(\Delta F /[\mathrm{L}])$, where $[\mathrm{L}]$ is the concentration of free oligonucleotide in the mixture [46]. The estimation error did not exceed $7-15 \%$.

\section{Analysis of proteins homology}

The homology of the protein sequences was analyzed using the LALIGN Server.

\section{Analysis of the LA tetramer structure}

The analysis of the packing of the subunits of LA in the crystal lattice was carried out for the structures of human LA from the PDB database with the identifiers 1HML [47] and 3B0I [48] using UnitCell and PropPDB AmberTools [49]. DNA structures of duplexes in B-form were predicted using the web server. Construction of a DNA complex with a LA tetramer is based on positional alignment; the number of contacts between the subunits was estimated using the developed Python scripts.

\section{Statistical analysis}

The results wear given as the mean \pm standard deviation of three independent experiments.

\section{Results}

\section{Purification and characterization of $\alpha$-lactalbumin}

In this work, electrophoretically homogeneous LA was purified from the milk of ten mothers by sequential chromatography of the milk proteins on phenyl-Sepharose and by then by gel-filtration on a Sephadex G-50 [45]. To analyze an "average" situation concerning homogeneity, we have prepared a mixture of equal amounts of LA preparations from the milk of ten mothers. The homogeneity of the typical $14-\mathrm{kDa}$ LA was confirmed by SDS-PAGE with silver staining, which showed a single band (Figure 1).

It was shown previously that LA forms oligomeric complexes. Therefore, we have analyzed a possible number of LA monomers in such complexes at the protein concentration $0.3 \mathrm{mg} / \mathrm{ml}$ using protein molecules crosslinking by glutaric dialdehyde. Figure 1 shows that after $1 \mathrm{~h}$ of the mixture incubation one can see that different complexes of crosslinked LA contain 2, 3 and 4 molecules of the protein. Under these conditions, the main form of the LA complex is a tetramer (Figure 1).

It was previously shown that human milk LA interacts with polymeric DNA [15]. First, we have shown that interaction of LA with different oligonucleotides leads to a significant loss in the fluorescence emission by the tryptophan residues of this protein. Then we tried to estimate a possible affinity of different oligonucleotides (ONs) to LA using quenching of fluorescence emission. Using the SILC approach we have analyzed the interaction of deoxy-(ODNs) and ribooligonucleotides (ORNs) of different structure and length with LA. Typical examples of the $K_{\mathrm{d}}$ values determination using the Scatchard plot are given in Figure 2.

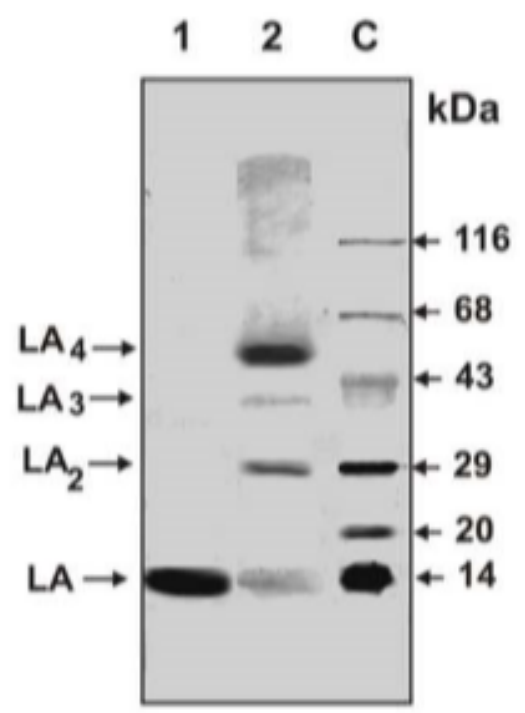

Figure 1: SDS-PAGE analysis of LA $(10 \mu \mathrm{g})$ corresponding to the mixture of the protein from milk of ten healthy mothers in a $4-18 \%$ gradient gel followed by silver staining (lane 1). Before electrophoresis LA $(0.3 \mathrm{mg} / \mathrm{ml})$ was incubated for $1 \mathrm{~h}$ at $22^{\circ} \mathrm{C}$ with $0.5 \mathrm{mM}$ glutaric dialdehyde (lane 2). LA, LA, $\mathrm{LA}_{3}$, and LA correspond to LA oligomer forms containing $1,2,3$, and 4 its monomers. The arrows (lane $\mathrm{C}$ ) indicate the positions of molecular mass markers. 
A

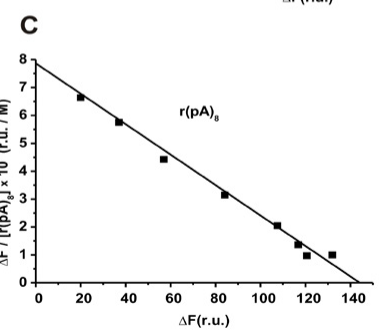

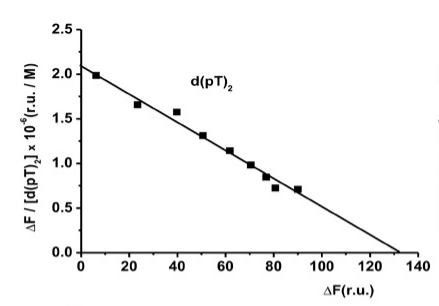

B

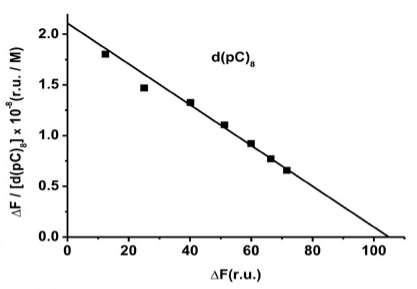

D

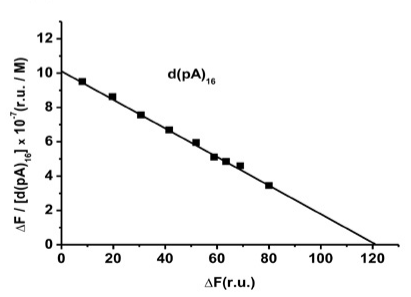

Figure 2: Typical Scatchard plots characterizing interaction of several $\mathrm{d}(\mathrm{pN})$ ${ }_{n}$ and $\mathrm{r}(\mathrm{pN})_{\mathrm{n}}$ with LA $(0.3 \mathrm{mg} / \mathrm{ml})$ as measured by quenching of the tryptophan fluorescence emission. Different ONs are shown on Panels A-D.

\section{Minimal ligands of LA DNA-binding site}

The formation of the LA $\times$ DNA complex was analyzed using the SILC approach, according to the following scheme: orthophosphate or mononucleotide (as minimal ligands of LA) $\rightarrow$ single-stranded homo$\mathrm{d}(\mathrm{N})_{\mathrm{n}} \rightarrow$ double-stranded homo-d $(\mathrm{N})_{\mathrm{n}}$.

Table 1 shows that the minimal ligands of LA DNA-binding site are orthophosphate $\left.\left(\mathrm{Pi} ; K_{\mathrm{d}}=1.0 \times 10^{-3} \mathrm{M}\right)\right)$. Transition from orthophosphate to $\operatorname{dTMP}\left(3.0 \times 10^{-4} \mathrm{M}\right)$, dCMP $\left(1.2 \times 10^{-4} \mathrm{M}\right)$, and dAMP $\left(5.0 \times 10^{-5}\right.$ $\mathrm{M})$ leads to the increase in the affinity respectively $\sim 3.3-, 8.3-$, and 20 fold; inverse values of these magnitudes correspond to the $K_{d}$ values: $0.3,0.12$, and $0.05 \mathrm{M}$ characterizing the affinity of this binding site for respective cytidine, thymidine, and adenosine of dNMPs.

LA also interacts with ribo-mononucleotides demonstrating comparable affinities: $\operatorname{rUMP}\left(4.3 \times 10^{-4} \mathrm{M}\right), \operatorname{rCMP}\left(3.0 \times 10^{-4} \mathrm{M}\right)$, and rAMP $\left(2.3 \times 10^{-4} \mathrm{M}\right)$. Only the affinity of LA for dAMP was significantly higher (4.6-fold) than that for rAMP, while ribo- and deoxy mononucleotides with other bases demonstrated comparable affinity (Tables 1 and 2).

\section{Interaction of LA with nucleotide units of single-stranded deoxyoligonucleotides}

The Gibbs' free energy for complex formation can be taken as the sum of the $\Delta G^{\circ}$ values for individual contacts [46]: $\Delta \mathrm{G}^{\circ}=\Delta \mathrm{G}^{\mathrm{o}}{ }_{1}+\Delta \mathrm{G}^{\mathrm{o}}{ }_{2}+\ldots$ $+\Delta \mathrm{G}^{\mathrm{o}}$, with $\Delta \mathrm{G}_{\mathrm{i}}^{\mathrm{o}}=-\mathrm{RT} \times \ln K_{\mathrm{d}}^{\mathrm{i}}$, where $K_{\mathrm{d}}{ }^{\mathrm{i}}$ indicates the contribution of the individual contact. The overall $K_{d}$ value for formation of the proteinDNA complex is the product of the $K_{\mathrm{d}}$ values for individual contacts: $\Delta \mathrm{G}^{\mathrm{o}}=-R T \ln K_{d}=R T \ln \left[\mathrm{K}_{d}(1) \times \mathrm{K}_{d}(2) \ldots \mathrm{K}_{d}(\mathrm{n})\right]$.

To assess possible additivity of LA interaction with different ONs, the data (Tables 1 and 2) were analyzed as logarithmic dependencies of $K_{d}$ for oligonucleotides versus the number of $\mathrm{d}(\mathrm{pN})_{\mathrm{n}}$ and $\mathrm{r}(\mathrm{pN})$ mononucleotide units $(n)$ (Figure $3 \mathrm{~A}$ and $3 \mathrm{~B}$ ). Usually the linear $\log$-dependencies for ss $\mathrm{d}(\mathrm{pN})_{\mathrm{n}}$ (for $0 \leq n \leq 7-20, \mathrm{n}=0$ corresponds to orthophosphate) provide evidence of the additivity of $\Delta G^{\circ}$ values for the interaction dependently of enzyme of 7-20 individual nucleotide units of $\mathrm{d}(\mathrm{pN})_{\mathrm{n}}$ and $\mathrm{r}(\mathrm{pN})_{\mathrm{n}}$ with DNA- and RNA-binding sites of many enzymes analyzed [26-44]. Interestingly, for LA nearly linear increase in the affinity $\left(-\log K_{\mathrm{d}}\right)$ was observed only for 5-6 nucleotides of ODNs
A

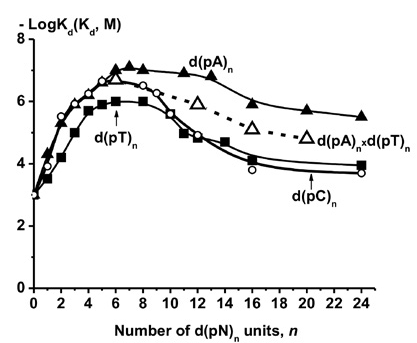

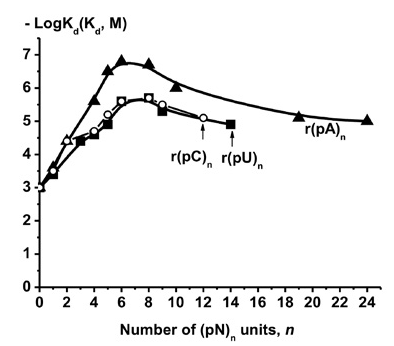

Figure 3: Logarithmic dependences of the $K_{d}$ values characterizing affinity of several ss $d(p N)_{n}$ and $r(p N)_{n}$ for LA. Different ss and ds ONs are shown on Panels $A$ and $B$. The average error in the $K_{d}$, and $\log K_{d}$ determination from twothree independent experiments did not exceed $10-15 \%$. Typical Scatchard plots characterizing the interaction of two $\mathrm{d}(\mathrm{pN})_{\mathrm{n}}$ duplexes with $\mathrm{LA}(0.3 \mathrm{mg} / \mathrm{ml})$ as measured by quenching of the tryptophan fluorescence emission; two different duplexes are shown on Panels $C$ and D.

and ORNs (Figure 3). The dependencies reach a temporary plateau at $\mathrm{n}=6-8$, and then there is a significant decrease in the affinity at $n \geq 8-9$ (Figure 3). The affinity of $\mathrm{d}(\mathrm{pT})_{6}\left(9.0 \times 10^{-7} \mathrm{M}\right)$ and $\mathrm{d}(\mathrm{pC})_{6}\left(2.1 \times 10^{-7}\right.$ M) was approximately 10 - and 2.4 -fold lower than that for $\mathrm{d}(\mathrm{pA})_{6}(8.8$ $\left.\times 10^{-8} \mathrm{M}\right)$. The affinity of $\mathrm{r}(\mathrm{pU})_{6}\left(2.2 \times 10^{-6} \mathrm{M}\right)$ and $\mathrm{r}(\mathrm{pC})_{6}\left(2.2 \times 10^{-6} \mathrm{M}\right)$ was the same, and approximately 15 -fold was lower than that for $\mathrm{r}(\mathrm{pA})_{6}$ $\left(1.5 \times 10^{-7} \mathrm{M}\right)$. Thus, $\mathrm{d}(\mathrm{pA})_{\mathrm{n}}$ and $\mathrm{r}(\mathrm{pA})_{\mathrm{n}}$ are the best ligands of LA DNAbinding site. In addition, $\mathrm{d}(\mathrm{pC})_{\mathrm{n}}$ and $\mathrm{d}(\mathrm{pT})_{\mathrm{n}}$ demonstrate higher affinity than $\mathrm{r}(\mathrm{pC})_{\mathrm{n}}$ and $\mathrm{r}(\mathrm{pU})_{\mathrm{n}}$ (Tables 1 and 2, Figure 3).

\section{Affinity of LA for DNA duplexes}

UDG "melts" ds $\mathrm{d}(\mathrm{pN})_{6-20}$ partially and contacts with both chains of such relatively short ODNs almost independently $[37,50]$. In contrast, DNA polymerases [30,31], AP endonuclease [33], Topo I [39,40], 8-oxoguanine-DNA glycosylases [34,38] interact with both basepaired DNA strands. However, the contribution of the second strand to the affinity of ds DNA for any enzyme is usually much lower than that to the first one. A peculiarity of the behavior of Topo I, DNA polymerases, and OGG1 is the "assembly" and subsequent stabilization of correct duplexes for which the melting temperature $\left(\mathrm{T}_{\mathrm{m}}\right)$ in solution is substantially lower than the complex formation at temperature used [38-40].

We have estimated the $K_{\mathrm{d}}$ values for duplexes (for example, Figure 3 and Table 1). The melting point of $\mathrm{d}(\mathrm{pA})_{6} \times \mathrm{d}(\mathrm{pT})_{6}$ is much lower $\left(\sim 0^{\circ} \mathrm{C}\right)$ than the temperature $\left(22^{\circ} \mathrm{C}\right)$ used in the $K_{\mathrm{d}}$ evaluation experiments. Under these conditions, there is no such complex, and the apparent value of $K_{\mathrm{d}}\left(1.8 \times 10^{-7} \mathrm{M}\right)$ for these ONs is closer to that for ss $\mathrm{d}(\mathrm{pA})_{6}\left(8.8 \times 10^{-8} \mathrm{M}\right)$ than for ss $\mathrm{d}(\mathrm{pT})_{6}\left(9.0 \times 10^{-7} \mathrm{M}\right)$ (Table 1$)$. Thus, in the absence of a duplex, $\mathrm{d}(\mathrm{pA})_{6}$ and $\mathrm{d}(\mathrm{pT})_{6}$ compete for LA and $\mathrm{d}(\mathrm{pA})_{6}$ having a higher affinity for the protein makes a greater contribution to the affinity of the mixture of the ONs for LA. The duplexes $\mathrm{d}(\mathrm{pA})_{12}$ $\times \mathrm{d}(\mathrm{pT})_{12}, \mathrm{~d}(\mathrm{pA})_{16} \times \mathrm{d}(\mathrm{pT})_{16}$, and $\mathrm{d}(\mathrm{pA})_{20} \times \mathrm{d}(\mathrm{pT})_{20}$, melting points of which are comparable or higher than $22^{\circ} \mathrm{C}\left(20,30.6\right.$, and $37.3^{\circ} \mathrm{C}$, respectively), they are characterized comparable affinity $\left(K_{\mathrm{d}}=(1.2-17)\right.$ $\times 10^{-5} \mathrm{M}$ in comparison with ss $\mathrm{d}(\mathrm{pT})_{12}-\mathrm{d}(\mathrm{pT})_{20}\left((1.5-11) \times 10^{-5} \mathrm{M}\right)$, but 9-38-fold lower than that for ss $\mathrm{d}(\mathrm{pA})_{12}-\mathrm{d}(\mathrm{pA})_{20}$ (Table 1). Thus, the affinity of duplexes for LA is significantly lower than for single-stranded ODNs.

\section{Thermodynamic model of LA interaction with short ODNs and ORNs}

All relatively small DNA-dependent globular enzymes (25-40 
$\mathrm{kDa})$ usually interact with 7-10 nucleotide units of DNA [24-42]. The molecular mass of LA is approximately $14.1 \mathrm{kDa}$. Taking into account the relatively low molecular mass of LA one can estimate approximately that the protein can cover about 5-7 nucleotides of DNA. All enzymes usually have several subsites (7-20 dependently enzyme) for interaction with mononucleotides of DNA [24-42]. One of these subsites has usually increased affinity for one nucleotide unit of DNA comparing with its other units. For example, the affinity of various free dNMP or one nucleotide unit of DNA in the case of these subsites of different enzymes varied approximately from $10^{-2}$ to $10^{-5} \mathrm{M}$, while other subsites demonstrated significantly lower affinity, 0.8-0.5 M [26-44]. In the case of different enzymes, these specific subsites of increased affinity are more often catalytic centers, and they usually disposed near the central part of the globular proteins [26-29]. Therefore, these subsites interact usually with the central nucleotide of DNA fragments "covered" by the enzymes. However, HIV-1 integrase recognizes 3'-terminal nucleotide of viral DNA with increased affinity [41].

We have estimated a relative contribution of different nucleotide units of $\mathrm{d}(\mathrm{pN})_{1-6}$ and $\mathrm{r}(\mathrm{pN})_{1-6}$ to the total affinity of single-stranded NAs to LA using $K_{\mathrm{d}}$ values; see the model of LA interaction with $\mathrm{d}(\mathrm{pN})_{1-7}$ and $\mathrm{r}(\mathrm{pN})_{1-7}$ (Figure 4). Only six nucleotide units of all ONs make an appreciable contribution to the effectiveness of their interaction with LA providing $\Delta \mathrm{G}^{\circ}$ of approximately from -7.21 to $9.53 \mathrm{kcal} / \mathrm{mol}$ (Figure 4). Interestingly, the affinity of LA specific subsite for one nucleotide unit of $\mathrm{d}(\mathrm{pA})_{1-6}\left(\Delta \mathrm{G}^{\circ}=5.8 \mathrm{kcal} / \mathrm{mol}\right)$ is significantly higher than that for $\mathrm{r}(\mathrm{pA})_{1-6}\left(\Delta \mathrm{G}^{\circ}=3.57 \mathrm{kcal} / \mathrm{mol}\right)$. However, the relative contribution of the second nucleotide unit of $\mathrm{d}(\mathrm{pA})_{1-6}\left(\Delta \mathrm{G}^{\circ}=1.32 \mathrm{kcal} / \mathrm{mol}\right)$ to its total affinity for LA is significantly lower than that for $\mathrm{r}(\mathrm{pA})_{1-5}\left(\Delta \mathrm{G}^{\circ}=2.37\right.$ $\mathrm{kcal} / \mathrm{mol})$. The contribution of one nucleotide unit of $\mathrm{d}(\mathrm{pT})_{1-6}$ and $\mathrm{d}(\mathrm{pC})_{1-6}\left(\Delta \mathrm{G}^{\circ}=4.55-4.76 \mathrm{kcal} / \mathrm{mol}\right)$ to the affinity for the protein is comparable to that for corresponding $\mathrm{r}(\mathrm{pU})_{1-6}$ and $\mathrm{r}(\mathrm{pC})_{1-6}\left(\Delta \mathrm{G}^{\circ}=4.55\right.$ $4.76 \mathrm{kcal} / \mathrm{mol}$ ) (Figure 4). It is interesting that depending on the base of $\mathrm{d}(\mathrm{pN})_{6}$ and $\mathrm{r}(\mathrm{pN})_{6}$, the contribution of each of the six nucleotide units may be significantly different (Figure 4 ).

\section{Construction of the model of LA interaction with ONs}

As shown above, the main oligomeric form of the LA under the analysis conditions used is the tetramer. To date, the crystal structure of the tetramer is unknown. Therefore, we analyzed the possible structure of the LA tetramer complex, based on the assumption that its structure can correspond to four interacting subunits of the LA crystal lattice. Using the results of the analysis (using the crystal structure of lactalbumin: PDB 1HML), we chose a tetramer structure that has the greatest number of contacts between neighboring subunits, since it must be the most stable structure. Then, the interaction of $\mathrm{ON}$ with the tetramer of LA was simulated.

It is known that sulfate ions usually interact with sites of protein for binding of phosphate groups, including internucleoside phosphate groups of DNA [51-53]. The analysis of the available crystalline structures of the LA in the PDB database made it possible to detect the presence of two sites of LA binding sulfate ions (PDB 1HML and 3B0I structures). As shown above, orthophosphate, the phosphate group of NMPs and one of the internucleoside phosphate groups of ONs have an increased affinity for LA (Table 1). We hypothesized that one or both of the sulfate ion binding sites in the structure of LA in principle could correspond to the sites of recognition of the phosphate groups of the NA ligands. One of these binding sites is located on the N-terminal part of the recombinant globular domain of LA, and the second is disposed at the interface of interaction of neighboring LA subunits in the crystalline package [48]. The sites of binding of sulfate ions are at a distance of $20 \dot{A}$ from each other, which corresponds to a distance of $\sim 8$ nucleotide pairs between the phosphate groups for neighboring DNA chains in the B form Figure 5. We analyzed the possible structure of the DNA complex with the obtained model of the LA tetramer, suggesting that the positions of the internucleoside phosphate groups of DNA in complex with the LA should coincide with the position of the sulfate ions binding sites (Figure 5).

As can be seen from Figure 3, an increase in the length $(\mathrm{pN})_{n}$ leads to an increase in affinity only up to $n=6-7$. It should be assumed that most likely, $(\mathrm{pN})_{6-7}$ effectively interact with only one of two sites for the binding of sulfate groups since a sharp increase in affinity for $n \geq 7$ is not observed Figures 3 and 4 . On the one hand, this may the result that the affinity for one of the two sites may be significantly higher than to another one, or during the adaptation of the structure $(\mathrm{pN})_{\mathrm{n}}$ and LA, the effective convergence of the AA residues of the protein and ON phosphate groups with one of the sites is not achieved. In addition, the sulfate ion binding sites observed in the recombinant globular domain structure of LA 3B0I may not be available in the full-length protein. A significant decrease in the affinity is particularly pronounced at $n \geq 9$ Figure 3, when $(\mathrm{pN})_{\mathrm{n}}$ can come into contact with neighboring globules of the protein, which should lead to steric hindrance of complex formation with one of the subunits.

\section{Analysis of possible causes of LA interaction with histones and chromatin DNA}

Of particular interest are the data that the LA binds to chromatin DNA, breaks its structure and prevents the histones complex from binding to DNA [7-9,12]. It is known that in the central, most conservative regions of the nucleosome core, hydrophobic AAs are

The relative contribution of six oligonucleotide units to their common affinity for LA

\begin{tabular}{|c|c|c|c|c|c|c|c|c|}
\hline \multirow{4}{*}{$\begin{array}{l}\mathrm{d}(\mathrm{pA})_{\mathrm{n}:} \\
\mathrm{d}(\mathrm{pT})_{\mathrm{n}} \\
\mathrm{d}(\mathrm{pC})_{\mathrm{n}}\end{array}$} & \multicolumn{7}{|c|}{$\Delta \mathbf{G}^{\mathbf{0}}, \mathrm{kcal} / \mathrm{mol}$} & \multirow[b]{2}{*}{ sum $=9.53$} \\
\hline & 5.8 & 1.32 & 0.38 & 0.85 & 0.59 & 0.59 & 0.0 & \\
\hline & 4.76 & 0.89 & 1.14 & 0.97 & 0.15 & 0.25 & 0.0 & $\operatorname{sum}=8.16$ \\
\hline & 4.55 & 0.72 & 0.70 & 0.20 & 0.60 & 0.44 & 0.0 & sum $=7.21$ \\
\hline & 1 & 2 & 3 & 4 & 5 & 6 & 7 & \\
\hline$(\mathrm{pA})_{\mathrm{n}}$ & 3.57 & 2.37 & 0.81 & 0.79 & 1.21 & 0.47 & 0.0 & sum $=9.22$ \\
\hline (pU) & 4.55 & 0.72 & 0.70 & 0.20 & 0.60 & 0.44 & 0.0 & $\operatorname{sum}=7.21$ \\
\hline$(\mathrm{pC})_{\mathrm{n}}$ & 4.76 & 1.24 & 0.35 & 0.65 & 0.60 & 0.67 & 0.0 & sum $=7.21$ \\
\hline
\end{tabular}

Figure 4: Thermodynamic model $\left(-\Delta \mathrm{G}^{\circ}\right.$ values) characterizing a relative contribution of different mononucleotides of $s \mathrm{~d}(\mathrm{pA})_{7}$ and ribo $(\mathrm{pA})_{7}$ to the total affinity of these $(\mathrm{pN})_{7}$ for LA. Different ss $(\mathrm{pA})_{7}$ are shown on the Panel.

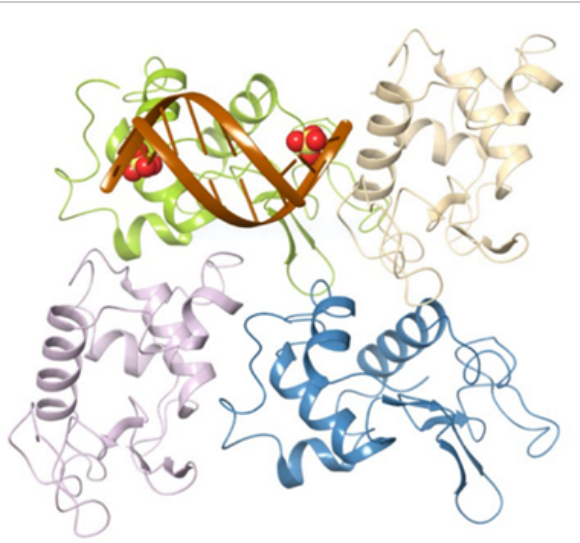

Figure 5: The calculated model of interaction of four subunits with the formation of the tetrameric form of LA and its interaction with an oligonucleotide. The model was constructed using $\mathrm{X}$-ray diffraction data for lactalbumin. DNA is indicated in red. 
prevail and they are necessary for the interaction between the histones (histones in pairs "recognize" each other). As a result, heterodimers are formed, which in turn form an octamer consisting of a tetramer of histones $\mathrm{H} 3-\mathrm{H} 4$ and two dimers $\mathrm{H} 2 \mathrm{a}-\mathrm{H} 2 \mathrm{~b}$ [54].

The possibility of interaction of LA with histones and nucleosome DNA can be related to the homology between LA and histones. We analyzed the global homology between LA and histones. It was revealed that $\mathrm{H} 2 \mathrm{a}$ histone has $14.4 \%$ full coincidence of the sequences of AAs (identity) and $41.1 \%$ similar in structure to AAs (similarity) with LA protein sequence. A similar situation is observed in the case of histone H3: $18.1 \%$ identical and $40.6 \%$ similar $\mathrm{AA}$ in $\mathrm{H} 3$ and LA sequences. However, the possibility of different proteins competition for the same ligands is generally not conditioned by their global, but by the homology of the local specific sequences interacting with these ligands, which for all histones is significantly higher.

Major, moderate and minor sites of specific cleavage of $\mathrm{H} 1, \mathrm{H} 2 \mathrm{a}$, and $\mathrm{H} 2 \mathrm{~b}[55,56]$, as well as $\mathrm{H} 3$ and $\mathrm{H} 4$ [57] histones with antibodies against these proteins having proteolytic activity (abzymes), were previously found. Interestingly, in accordance with the crystal structure of the nucleosome core, some AA residues located in the abzymedependent cleavage sites of $\mathrm{H} 3, \mathrm{H} 4, \mathrm{H} 2 \mathrm{a}$, and $\mathrm{H} 2 \mathrm{~b}$ are directly involved in the interaction of these histones with the DNA of the nucleosome [55-57]. In the core of the nucleosome, most major and moderate cleavage sites $\mathrm{H} 2 \mathrm{a}$ and $\mathrm{H} 2 \mathrm{~b}$ are involved in the interaction between these histones [56]. Minor H2a cleavage sites are involved in binding to histone $\mathrm{H} 3$ in nucleosomes. Two moderate $\mathrm{H} 2 \mathrm{~b}$ sites and one major cleavage site for $\mathrm{H} 2 \mathrm{a}$ are located in the disordered $\mathrm{N}$-terminal region of these histones interacting with the DNA of the chromosome nucleus [56]. According to the crystal structure of the nucleosomal nucleus [58], all identified cleavage sites should influence the interaction of $\mathrm{H} 2 \mathrm{a}$ and $\mathrm{H} 2 \mathrm{~b}$, the assembly of nucleosomes, and the binding of $\mathrm{H} 2 \mathrm{a}$ and $\mathrm{H} 2 \mathrm{~b}$ to DNA [56].

Taking this into account, we have analyzed a possible homology of the abzyme-dependent cleavage sites of all histones with the protein sequence of LA. As one can see from Figure 6, most of the sites of abzyme-dependent hydrolysis of all five histones have a high level of homology with different fragments of the protein sequence of LA. In Figure 6 all sequences of LA that are homologous with the cleavage sites of all five histones are marked in bold. It is interesting that as a whole, $52 \%$ of AA residues of LA have homology (identity) with different specific cleavage sites of five histones Figure 6 . Thus, it should be assumed that the homology of the protein sequence of LA with sequences of the histones involved in the interaction between themselves and with DNA of the chromatin nucleus can provide competition of LA for its binding with histones and DNA. This can be the main reason for the interaction of LA with chromatin DNA, leading to a breakdown in its structure, as well as prevent histones to interact with each other and with DNA.

\section{Discussion}

It was revealed that the minimal ligands of all DNA-binding proteins are orthophosphate, dNMPs, and rNMPs [26-44]. The high affinity of different sequence-specific and nonspecific DNA-dependent enzymes (repair, topoisomerization, restriction, and integration) is usually provided by a superposition of different strong and weak contacts. The affinity of nonspecific dNMPs to the active centers of sequence-specific enzymes is usually only 2-20-fold lower than for specific nucleotides [26-44]. Then at lengthening of $\mathrm{d}(\mathrm{pN})_{\mathrm{n}}$, by one nucleotide unit usually there is a monotonic increase in the affinity dependently on enzyme by a factor of 1.2-2.6 up to $n=7-20$ [26-44].
A

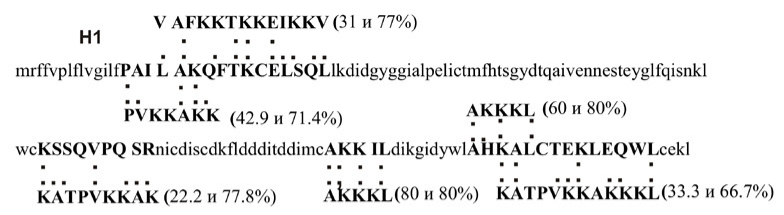

B

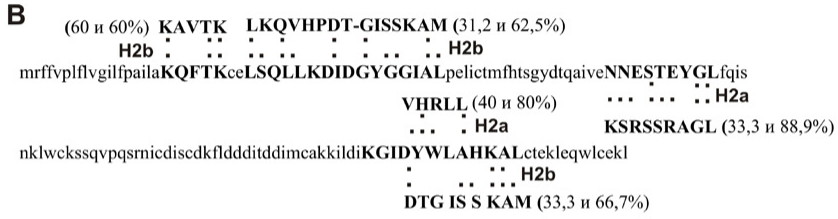

C

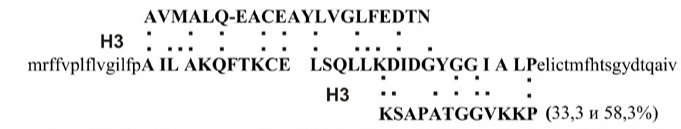

KSAPATGGVKKP (33,3 и 58,3\%)
ennesteyglfqisnklwckssqvpqsrnicdiscdkflddditddimcaKKIL--DIKGIdywlahkalctekleqwlcekl

D $\because \quad \therefore \quad \because$ н4
RKVLRDNIQGI $(45,8$ и $81,8 \%)$

mrffvplflvgilfPAILAKOFTKCELSOLLKDIDGYGGIALPelictmfhtsgydtqaiveNNESTEYG LfqisnklwcKSSOVPOSRnicdiscdkflddditddimc AKKILDIKGIDYWLAHKALCTEKLEQW lcekl

Figure 6: Specific cleavage sites for $\mathrm{H} 1, \mathrm{H} 2 \mathrm{a}, \mathrm{H} 2 \mathrm{~b}, \mathrm{H} 3$, and $\mathrm{H} 4$ with abzyme antibodies against these histones involved in the interaction between histones and their complex with the DNA of the nucleosomal core are shown in bold on panels A-C. These sites are homologous to certain fragments of the lactalbumin sequence: the complete coincidence of AA residues is indicated with the help of colons, and the structural similarity by points. The panel $D$ summarizes all sequences of LA having homology with fragments of all five histones.

The similar situation is observed for a-lactalbumin efficiently interacting with orthophosphate, mononucleotides, all $\mathrm{d}(\mathrm{pN})_{2-7}$ and $\mathrm{r}(\mathrm{pN})_{2-7}$ (Tables 1, 2, Figures 3 and 4); the LA interaction only with six nucleotide units is consistent with its relatively low molecular mass $(\sim 14.1 \mathrm{kDa})$.

Usually, typical linear dependences of $-\log K_{\mathrm{d}}$ upon $n$ reach a constant plateau at $n$ corresponding the number of nucleotide units covered by proteins [26-44]. In the case of LA, the temporary plateau one can see only at $n=6-8$, while at $\mathrm{n} \geq 9$ a significant decrease in the affinity of ONs is observed Figure 3. We simulated the tetrameric form of LA and its interaction with DNA using data of X-ray diffraction analysis of LA. As can be seen from Figure 5, only 6-7 nucleotide pairs of DNA may be in contact with every one of the four globules of LA. The neighboring globules of the tetramer create steric hindrances for ON interaction simultaneously with two subunits, which can sterically disrupt the effective interaction of $\mathrm{d}(\mathrm{pN})_{\mathrm{n}>8}$ with one of them. The affinity of $\mathrm{d}(\mathrm{pA})_{\mathrm{n}} \times \mathrm{d}(\mathrm{pT})_{\mathrm{n}}$ duplexes for LA is lower than for singlestranded ONs. Therefore, it should be noted that DNA polymerases, apurin-apyrimidine endonuclease, topoisomerase I, and repair enzymes interact with both chains of dsDNA [26-44]. The peculiarity of the behavior of topoisomerase I, DNA polymerases, and human 8-oxoguanine-DNA glycosylase is that short complementary $\mathrm{d}(\mathrm{pN})_{6}$ ${ }_{9}$, in solution at the temperature of the reaction mixture do not form duplexes, but their affinity for enzymes approximately one order of magnitude higher than for ss ONs. Consequently, these enzymes themselves "assemble" and subsequently stabilize these short duplexes due to the interaction of both ON chains not only with each other but also with the enzymes. However, the contribution of the second chain to the affinity of ds DNA to any enzyme is usually much less than the contribution of the first chain, or it is almost completely absent [26- 
Citation: Nevinsky GA, Alinovskaya LI, Ivanisenko NV, Soboleva SE, Sedykh SE (2018) How Human Alpha-lactalbumin Recognize DNA and RNA (Avocardo) Seed Oil Using Gas Chromatography-Mass Spectroscopy. Biochem Anal Biochem 7: 363. doi: 10.4172/2161-1009.1000363

Page 7 of 8

44]. The lower affinity of the LA for ds ONs comparing to ss $\mathrm{d}(\mathrm{pN})_{6}$. ${ }_{9}$ indicates that the LA does not stabilize short duplexes. In addition, even preformed in solution duplexes of long ONs demonstrate a lower affinity for LA compared to ss $\mathrm{d}(\mathrm{pN})_{\mathrm{n}>16}$.

LA binds to chromatin DNA, breaks its structure and prevents proper binding of histones with DNA [12]. The possibility of interaction of LA with histones, and nucleosome DNA may be related to the high homology between several fragments of several protein sequences of histones and LA Figure 6. Some IgG-dependent cleavage sites for $\mathrm{H} 3, \mathrm{H} 4, \mathrm{H} 2 \mathrm{a}$, and $\mathrm{H} 2 \mathrm{~b}$ directly participate in the interaction between these histones and their complex with nucleosome DNA [5557]. Interestingly, these cleavage sites of the histones have increased homology with several sequences of LA; identity of different protein sequences varies from 31.2 to $60 \%$, while similarity from 58.3 to $88.9 \%$ Figure 6. It cannot be ruled out that the homology of the protein sequence of LA with sequences of the histones involved in interaction between themselves and with the chromatin DNA is the main reason for the competition of LA for binding both with histones and DNA and disturbances of the correct binding of histones to each other and to DNA.

Thus, in this work, the contribution of various links of ( $\mathrm{pN})_{n}$ to their affinity for LA is estimated for the first time, and the possible causes of the interaction of this protein with histones and chromatin DNA of the cell nucleus are analyzed.

\section{Acknowledgements}

This research was supported by the grant from the grants of Russian Foundation for Basic Research (No. 16-04-00609 and 16-04-00603) and Russian State funded budget project (VI.62.1.5, 0309-2016-0003).

\section{References}

1. Jensen RC, Ferris, AM, Lammi-Keefe CJ (1991) The composition of milk fat. J Dairy Sci 74: 3228-3243.

2. Hambraeus L (1977) Proprietary milk versus human breast milk in infant feeding. Pediatr Clin North Am 24: 17-36.

3. Phillips NI, Jenness R (1971) Isolation and properties of human a-lactalbumin. Biochim Biophys Acta 229: 407-410.

4. Lönnerdal B, Glazier C (1985) Calcium-binding by a-lactalbumin in human milk J Nutr 115: 1209-1216.

5. Grobler JA, Wang M, Pike AK, Brew K (1994) Study by mutagenesis of the roles of two aromatic clusters of alpha-lactalbumin in aspects of its action in the lactose synthase system. J Biol Chem 269: 5106-5114.

6. Svensson M, Sabharwal H, Hakansson A, Mossberg AK, Lipniunas $P$, et al. (1999) Molecular characterization of alpha-lactalbumin folding variants that induce apoptosis in tumor cells. J Biol Chem 274: 6388-6396.

7. Köhler C, Håkansson A, Svanborg C, Orrenius S, Zhivotovsky B (1999) Protease activation in apoptosis induced by MAL. Exp Cell Res 249: 260-268.

8. Håkansson A, Zhivotovsky B, Orrenius S, Sabharwal H, Svanborg C (1995) Apoptosis induced by a human milk protein. Proc Natl Acad Sci USA 92: 8064-8068.

9. Svensson M, Håkansson A, Mossberg AK, Linse S, Svanborg C (2000) Conversion of alpha-lactalbumin to a protein inducing apoptosis. Proc Natl Acad Sci USA 97: 4221-4226.

10. Permyakov SE, Knyazeva EL, Khasanova LM, Fadeev RS, Zhadan AP, et al (2012) Oleic acid is a key cytotoxic component of HAMLET-like complexes. Biol Chem 393: 85-92.

11. Nemashkalova EL, Kazakov AS, Khasanova LM, Permyakov EA, Permyakov SE (2013) Structural characterization of more potent alternatives to HAMLET, a tumoricidal complex of $\alpha$-lactalbumin and oleic acid. Biochemistry 52: 62866299.

12. Düringer C, Hamiche A, Gustafsson L, Kimura H, Svanborg C (2003) HAMLET interacts with histones and chromatin in tumor cell nuclei. J Biol Chem 278: 42131-42135.
13. Alberts B (1998) The cell as a collection of protein machines: preparing the next generation of molecular biologists. Cell 92: 291-294.

14. Eubel H, Braun HP, Millar AH (2005) Blue-native PAGE in plants: a tool in analysis of protein-protein interactions. Plant Methods 16: 1-11.

15. Lönnerdal B (2003) Nutritional and physiologic significance of human milk proteins. Am J Clin Nutr 77: 1537S-1543S

16. Soboleva SE, Dmitrenok PS, Verkhovod TD, Buneva VN, Sedykh SE, et al (2015) Very stable high molecular mass multiprotein complex with DNase and amylase activities in human milk. J Mol Recognit 28: 20-34.

17. Mitra A, Chattoraj DK, Chakraborty $P$ (2001) Binding of globular proteins to DNA from surface tension measurement. Indian J Biochem Biophys 38: 313320.

18. Freemont PS, Lane AN, Sanderson MR (1991) Structural aspects of proteinDNA recognition. Biochem J 278: 1-23.

19. Phillips SEV, Moras D (1999) Protein-nucleic acid interactions. Curr Opin Struct Biol 9: 11-13.

20. Tainer JA, Friedberg EC (2000) Dancing with the elephants: envisioning the structural biology of DNA repair pathways. Mutat Res 460: 139-141.

21. Luscombe NM, Austin SE, Berman HM, Thornton JM (2000) An overview of the structures of protein-DNA complexes. Genome Biol 1:1-37.

22. Pingoud A, Jeltsch A (2001) Structure and function of type II restriction endonucleases. Nucleic Acids Res 29: 3705-3727.

23. Rice PA, Baker TA (2001) Comparative architecture of transposase and integrase complexes. Nat Struct Biol 8: 302-307.

24. Aggarwal AK, Doudna JA (2003) Protein-nucleic acid interactions. Curr Opin Struct Biol 13: 3-5

25. Boehr DD, Nussinov R, Wright PE (2009) The role of dynamic conformational ensembles in biomolecular recognition. Nat Chem Biol 5: 789-796.

26. Nevinsky GA (1995) An important role of weak interactions in long DNA and RNA molecule recognition by enzymes. Mol Biol (Moscow) 29: 16-37.

27. Nevinsky GA (2003) Structural, thermodynamic, and kinetic basis of DNA and RNA-dependent enzymes functioning: important role of weak nonspecific additive interactions between enzymes and long nucleic acids for their recognition and transformation. In: Uversky VN, editor. Protein Structures Kaleidoscope of Structural Properties and Functions. Research Signpost: Kerala 133-222.

28. Nevinsky GA (2004) The role of weak specific and nonspecific interactions in enzymatic recognition and conversion of long DNAs. Mol Biol (Mosk) 38: 636662.

29. Nevinsky GA (2011) Structural, thermodynamic, and kinetic basis for the activities of some nucleic acid repair enzymes. J Mol Recognit 24: 656-677.

30. Nevinsky GA, Veniaminova AG, Levina AS, Podust VN, Lavrik OI, et al. (1990) Structure-function analysis of mononucleotides and short oligonucleotides in the priming of enzymatic DNA synthesis. Biochem 29: 1200-1207.

31. Kolocheva TI, Nevinsky GA, Levina AS, Khomov VV, Lavrik OI (1991) The mechanism of recognition of templates by DNA polymerases from pro- and eukaryotes as revealed by affinity modification data. J Biomol Struct Dyn 9 . 169-186.

32. Kolocheva TI, Maksakova GA, Bugreev DV, Nevinsky GA (2001) Interaction of endonuclease EcoRI with short specific and nonspecific oligonucleotides. IUBMB Life 51: 189-195.

33. Beloglazova NG, Kirpota OO, Starostin KV, Ishchenko AA, Yamkovoy VI, et al (2004) Thermodynamic, kinetic and structural basis for recognition and repair of abasic sites in DNA by apurinic/apyrimidinic endonuclease from human placenta. Nucleic Acids Res 32: 5134-5146.

34. Ishchenko AA, Vasilenko NL, Sinitsina OI, Yamkovoy VI, Fedorova OS, et al. (2002) Thermodinamic, kinetic, and structural basis for recognition and repair of 8-oxoguanine in DNA by Fpg protein from E. coli. Biochemistry 41: 7540-7548.

35. Vinogradova NL, Bulychev NV, Maksakova GA, Johnson F, Nevinskii GA (1998) Uracil DNA glycosylase: Interpretation of X-ray data in the light of kinetic and thermodynamic studies. Mol Biol (Mosk) 32: 489-499.

36. Zharkov DO, Ishchenko AA, Douglas KT, Nevinsky GA (2003) Recognition of 
Citation: Nevinsky GA, Alinovskaya LI, Ivanisenko NV, Soboleva SE, Sedykh SE (2018) How Human Alpha-lactalbumin Recognize DNA and RNA (Avocardo) Seed Oil Using Gas Chromatography-Mass Spectroscopy. Biochem Anal Biochem 7: 363. doi: 10.4172/2161-1009.1000363

damaged DNA by Escherichia coli Fpg protein: Insights from structural and kinetic data. Mutat Res 531: 141-156.

37. Zharkov DO, Mechetin GV, Nevinsky GA (2010) Uracil-DNA glycosylase: Structural, thermodynamic and kinetic aspects of lesion search and recognition. Mutat Res 685: 11-20.

38. Kirpota OO, Endutkin AV, Ponomarenko MP, Ponomarenko PM, Zharkov DO, et al. (2011) Thermodynamic and kinetic basis for recognition and repair of 8-oxoguanine in DNA by human 8-oxoguanine-DNA glycosylase. Nucleic Acids Res 39: 4836-4850.

39. Bugreev DV, Buneva VN, Sinitsyna OI, Nevinsky GA (2003) The mechanism of the supercoiled DNA recognition by the eukaryotic type I topoisomerases. I. The enzyme interaction with nonspecific oligonucleotides. Bioorg khim 29: 143-153.

40. Bugreev DV, Sinitsyna OI, Buneva VN, Nevinsky GA (2003) The mechanism of supercoiled DNA recognition by eukaryotic type I topoisomerases. II. A comparison of the enzyme interaction with specific and nonspecific oligonucleotides. Bioorg Khim 29: 277-289.

41. Bugreev DV, Baranova S, Zakharova OD, Parissi V, Desjobert C, et al. (2003) Dynamic, thermodynamic, and kinetic basis for recognition and transformation of DNA by human immunodeficiency virus type 1 integrase. Biochemistry 42 9235-9247.

42. Bugreeva IP, Bugreev DV, Nevinsky GA (2005) Formation of nucleoprotein RecA filament on single-stranded DNA: Analysis by stepwise increase in ligand complexity. FEBS J 272: 2734-2745.

43. Bugreeva IP, Bugreev DV, Nevinskii GA (2007) Interaction of single-stranded DNA with the second DNA-binding site of RecA nucleoprotein filament. Mol Biol (Mosk) 41: 524-534.

44. Guschina TA, Soboleva SE, Nevinsky GA (2013) Recognition of specific and nonspecific DNA by human lactoferrin. J Mol Recognit 26: 136-148.

45. Lindahl L, Vogel HJ (1984) Metal-ion-dependent hydrophobic-interaction chromatography of alpha-lactalbumins. Anal Biochem 140: 394-402.

46. Fersht A (1985) Enzyme Structure and Mechanism. (2ndedn), New York, USA, W H Freeman Company.
47. Ren J, Stuart DI, Acharya KR (1993) Alpha-lactalbumin possesses a distinct zinc binding site. J Biol Chem 268: 19292-19298.

48. Makabe K, Nakamura T, Kuwajima K (2012) Structural insights into the stability perturbations induced by $\mathrm{N}$-terminal variation in human and goat $\alpha$-lactalbumin Protein Eng Des Sel 26: 165-170.

49. Case DA, Cerutti DS, Cheatham TE III, Darden TA, Duke RE, et al. (2017) AMBER, University of California, San Francisco.

50. Vinogradova NL, lamkovol VI, Tsvetkov IV, Nevinskil GA (1996) Interaction of uracil-DNA-glycosylase from human placenta with single-stranded deoxy- and oligoribonucleotides and their complexes. Mol Biol (Mosk) 30: 209-219.

51. Eriksen TA, Kadziola A, Bentsen AK, Harlow KW, Larsen S (2000) Structura basis for the function of Bacillus subtilis phosphoribosyl-pyrophosphate synthetase. Nat Struct Biol 7: 303-308.

52. Nishino T, Komori K, Tsuchiya D, Ishino Y, Morikawa K (2001) Crystal structure of the archaeal holliday junction resolvase $\mathrm{Hjc}$ and implications for DNA recognition. Structure 9: 197-204.

53. Kaminski PA, Labesse G (2013) Phosphodeoxyribosyltransferases, designed enzymes for deoxyribonucleotides synthesis. J Biol Chem 288: 6534-6541.

54. Koryakov DE (2006) Modifications of histones and regulation of chromatin work. Genet 42: 1170-1185.

55. Baranova SV, Dmitrienok PS, Ivanisenko NV, Buneva VN, Nevinsky GA (2017) Antibodies to $\mathrm{H} 1$ histone from the sera of HIV-infected patients recognize and catalyze site-specific degradation of this histone. J Mol Recognit Mar 30.

56. Baranova SV, Dmitrienok PS, Ivanisenko NV, Buneva VN, Nevinsky GA (2017) Antibodies to $\mathrm{H} 2 \mathrm{a}$ and $\mathrm{H} 2 \mathrm{~b}$ histones from the sera of HIV-infected patients catalyze site-specific degradation of these histones. Mol Biosyst 13: 1090-1101.

57. Baranova SV, Dmitrienok PS, Zubkova AD Ivanisenko NV, Odintsova ES, et al. (2018) Antibodies against $\mathrm{H} 3$ and $\mathrm{H} 4$ histones from the sera of HIV-infected patients catalyze site-specific degradation of these histones. J Mol Recognit 31: e2703.

58. Davey CA, Sargent DF, Luger K, Maeder AW, Richmond TJ (2002) Solven mediated interactions in the structure of the nucleosome core particle at $1.9 \AA$ resolution. J Mol Biol 319: 1097-1113. 